\title{
Identification of amyloid $\beta$-peptide responsive genes by CDNA microarray technology: Involvement of RTP801 in amyloid $\beta$-peptide toxicity
}

\author{
Jae-Ryong Kim ${ }^{1,4}$, Seung-Rock Lee ${ }^{2}$ \\ Hyun Jin Chung ${ }^{1}$, Seongyong Kim ${ }^{1}$ \\ Suk-Hwan Baek ${ }^{1}$, Jung Hye Kim ${ }^{1}$ \\ and Yong-Sun $\mathrm{Kim}^{3}$ \\ ${ }^{1}$ Department of Biochemistry and Molecular Biology \\ College of Medicine \\ Yeungnam University, Daegu 705-717, Korea \\ ${ }^{2}$ Center for Cell Signaling Research \\ Division of Molecular Life Sciences \\ and Department of Biological Sciences \\ Ewha Womans University, Seoul 120-750, Korea \\ ${ }^{3}$ Institute of Environment \& Life Science \\ Hallym Academy of Sciences \\ Hallym University, Anyang 431-060, Korea \\ ${ }^{4}$ Corresponding Author: Tel, 82-53-620-4342; \\ Fax, 82-53-654-6651; Email, kimjr@med.yu.ac.kr
}

Accepted 26 September 2003

Abbreviations: $A \beta$, Amyloid $\beta$-peptide; AD, Alzheimer's disease; CDK, cyclin-dependent kinase; DMEM, Dulbecco's modified Eagle's medium; DSCR1, Down syndrome candidate region 1; MTT, 3- (4, 5-dimethylthiazol-2-yl)-2, 5-diphenyltetrazolium bromide; RT$P C R$, reverse transcription polymerase chain reaction; SDS, sodium dodecylsulfate; SEST2, Hi95/sestrin 2; STC, stanniocalcin; ZFP36L2, zinc finger protein 36 .

\footnotetext{
Abstract

Amyloid $\beta$-peptide $(A \beta)$, a causative molecule in the pathogenesis of Alzheimer's disease and the main component of senile plaques, is known to be neurotoxic in vitro and in vivo. The mechanisms involved in this $A \beta$-mediated neurotoxicity are not fully understood, although there is evidence to suggest the involvement of oxidative stress, alterations in calcium homeostasis, and/or of CDK activators. Many studies have suggested that $A \beta$ may exert its toxic effect via the activation of transcription factors. Therefore, we investigated $A \beta$ responsive genes in human neuroblastoma CHP134 cells using $3.1 \mathrm{~K}$ human DNA microarrays. Among the several genes overexpressed or repressed by A $\beta, R T P 801, H i 95 /$ sestrin 2, and stanniocalcin 2 were confirmed to be $A \beta$-mediated overexpression
}

in the cells by semiquantitative RT-PCR. Transient expression of the sense RTP801 gene in CHP134 cells increased sensitivity to $A \beta$ cytotoxicity and the expression of the antisense RTP801 gene protected the cells from the $A \beta$ toxicity. These results suggest that RTP801 might play important roles in $A \beta$ toxicity and the pathogenesis of Alzheimer's disease.

Keywords: amyloid $\beta$-peptide, cDNA microarray, cytotoxicity, RTP801

\section{Introduction}

Alzheimer's disease $(A D)$ is one of the major causes of senile dementia. It is a neurodegenerative disorder, which results in the disturbance of learning and memory. Pathologically, insoluble aggregates (amyloid plaques) consisting of amyloid $\beta$ peptide $(A \beta)$ and cytoskeletal proteins are characteristics of the disease (Mark et al., 1996). The mechanisms involved in the A $\beta$-mediated neurotoxicity are not fully understood, although a variety of evidence suggests the involvement of oxidative stress (Markesbery, 1997; Miranda et al., 2000; Smith et al., 2000), alterations in calcium homeostasis (Mattson et al., 1998), and/or of CDK activators (Maccioni et al., 2001). Substantial evidence is available to show the involvements of oxidative stress in AD pathogenesis; i) increments of metal ions which accelerate the formation of free radicals (Thompson et al., 1988; Suh et al., 2000), ii) an increase in the oxidation of lipid (Butterfield et al., 1994; Schippling et al., 2000), protein (Smith et al., 1991; Aksenov et al., 1997) and DNA (Lovell et al., 1999), iii) the presence of advanced glycation end products (AGE) (Vitek et al., 1994), malondialdehyde, peroxynitrite, heme oxygenase-1, superoxide dismutase-1 in neurofilament tangles or senile plaques (Pappolla et al., 1992), and iv) production of hydrogen peroxide by $\beta$-amyloid peptide (Behl et al., 1994; Huang et al., 1999).

Increments of oxidative stress by $A \beta$ result in the activation of various transcription factors, including NF-אB (Behl et al., 1994; Kaltschmidt et al., 1996) and AP-1 (Marcus et al., 1998; Jang and Surh, 2002). Thus, several studies have been applied to explore $A \beta$-responsive genes to gain an insight into the mole- 
cular mechanisms underlying $A \beta$ toxicity. $B c l-2, B a x$ (Paradis et al., 1996), and superoxide dismutase (Aksenov et al., 1998), participated in apoptosis and oxidative stress, were found to be differentially expressed by $A \beta$. Other studies have been undertaken without the limitations imposed by an a priori hypothesis. Gadd45 (Santiard-Baron et al., 1999) and Seladin-1 (Greeve, et al., 2000) were identified as A $\beta$-responsive genes by RNA differential displays. Recent advances in cDNA array technology have made it possible to analyze global gene expressions (Park et al., 2002). Calcineurin $A \beta$ was also identified to be upregulated in $A D$ brains by CDNA microarray technology (Hata et al., 2001) and interleukin-8 was found to be overexpressed in $A \beta$-stimulated postmortem brain microglia (Walker et al., 2001).

In this study, we set out to identify genes differentially expressed in human neuroblastoma CHP134 cells treated with $A \beta$ by using cDNA microarray technology, and we found that RTP801, Hi95/sestrin 2 and stanniocalcin 2 (STC2) were overexpressed in A $\beta$-treated CHP134 cells. Furthermore, the transient expression of RTP801 in CHP134 cells increased A $\beta$ or hydrogen peroxide-mediated cytotoxicity.

\section{Materials and Methods}

\section{Materials}

KNU 3.1K DNA chips were from Tricogene (Daegu, Korea). $\beta$-amyloid peptide (1-42) was from the American Peptide Company (Sunnyvale, CA). Dulbecco's modified Eagle's medium (DMEM), Pfx Taq polymerase, Superscript II reverse transcriptase, and a penicillin-streptomycin-fungizone antibiotic solution were from Life technologies, Inc. (Gaithersburg, MD). A pCR3.1 TA cloning kit was from Invitrogen Corp. (CarIsbad, CA), a Ready-to-go T4 DNA ligase mix from Amersham Pharmacia Biotech. (Piscataway, NJ), and gel extraction kits from Qiagen Inc. (Valencia, CA). Primers for $A \beta$-responsive genes and cloning of RTP801 and STC2 were from Biobasic Inc. (Canada) and are listed in Table 1.

\section{Cell culture and $A \beta$ treatment}

CHP134 cells were maintained in DMEM containing $10 \%$ FBS and antibiotics. $A \beta(1-42)$ was dissolved in sterile DW. For all subsequent experiments, cells were treated with $10 \mu \mathrm{M} \mathrm{A} \beta$ in DMEM +2\% FBS for the indicated times.

\section{3-(4,5-dim ethylthiazol-2-yl)-2,5-diphe nyltetrazolium bromide (MTT) assay \\ CHP134 cells were seeded in 96 well plates $\left(2 \times 10^{4}\right.$}

cells/well) in DMEM containing 2\% FBS and antibiotics and incubated for 1 day. After discarding the media, cells were treated with $A \beta$ at the indicated concentrations for $48 \mathrm{~h}$. Twenty five $\mu$ of MTT solution $(5 \mathrm{mg} / \mathrm{ml}$ in PBS) was then added into the wells and incubated for $4 \mathrm{~h}$ at $37^{\circ} \mathrm{C}$. The MTT solution was discarded by aspiration, and the resulting formazan products converted by the viable cells were dissolved in $100 \mu \mathrm{l}$ of dimethyl sulfoxide. Absorbance at 570 $\mathrm{nm}$ was measured using a BioRad M450 microplate reader. Cell survival was expressed as a percentage of $A \beta$-untreated control cells.

\section{Total RNA and mRNA preparation}

Total RNAs were extracted from CHP134 cells treated with or without $10 \mu \mathrm{M} \mathrm{A} \beta$ for $1 \mathrm{~h}$ and for $6 \mathrm{~h}$ by acid-phenol-guanidinium thiocyanate-chloroform extraction (Chomczynski and Sacchi, 1987). mRNAs were purified using an Oligotex mRNA purification kit (Qiagen Inc.).

\section{Fluorescence-labeled cDNA probe preparation and hybridization}

Fluorescence-labeled cDNAs were prepared from mRNAs by RT reaction using the aminoallyl labeling method (http://www.tigr.org/tdb/microarray/protocolsTIGR. shtml). The slides were prehybridized in $0.1 \%$ SDS, $5 X$ SSC and $1 \%$ bovine serum albumin for $45 \mathrm{~min}$ and then hybridized with fluorescence-labeled cDNA probes in $50 \%$ formamide, $5 X$ SSC, and $0.1 \%$ SDS, $1 \mu \mathrm{g} / \mu \mathrm{l}$ cot1 DNA, $1 \mu \mathrm{g} / \mu \mathrm{l}$ poly (A)-DNA for 16-20 h. The slides were then washed in $1 \mathrm{X}$ SSC and $0.2 \%$ SDS at $42^{\circ} \mathrm{C}$ for $4 \mathrm{~min}$ and in $0.1 \mathrm{X}$ SSC and $0.2 \%$ SDS at room temperature for $4 \mathrm{~min}$.

\section{Scanning and image analysis}

Fluorescence intensities at immobilized targets were measured using Scanarray 4,000 with a laser confocal microscope (GSI Lumonics). The two fluorescent images (Сy3 and Cy5) were scanned separately from a confocal microscope and analyzed using Quantarray software (version 2.0.1, GSI Lumonics). Results were also analyzed by normalizing images to adjust for the different labeling and detection efficiencies at the two different fluorescent wavelengths. We used a filter that included all genes exhibiting a minimum level of expression intensity of more than 1,000 fluorescent units (on a scale of $0-65,535$ fluorescent units) for both red and green channels for each experiment.

\section{Reverse transcription-polymerase chain reaction ( $R T-P C R$ )}

To confirm the differential expressions of genes screen- 
Table 1. Primers of AB-responsive genes for RT-PCR.

\begin{tabular}{|c|c|c|}
\hline Genes & Sequences & Size $(b p)$ \\
\hline RTP801 & $\begin{array}{l}\text { RTP-1056F: CATTGAGTTGTGTGCGGG } \\
\text { RTP-1521R: AGGCTTAAACGCAGCTGC } \\
\text { RTP-193F TCACCATGCCTAGCCTTTG } \\
\text { RTP-913R CCCCCTCAGGTTGAAGTTC }\end{array}$ & 721 \\
\hline Hi95/Sestrin 2 (SEST2) & $\begin{array}{l}\text { SES-744F: CTTAGGTGGCACCATGGC } \\
\text { SES-1082R: TTCTGCCTGGAAGCAACC }\end{array}$ & 339 \\
\hline Down syndrome candidate region 1 (DSCR1) & $\begin{array}{l}\text { DSCR-1401F: TTTGGGATCGGACCTCAG } \\
\text { DSCR-2044R: GTCTCTCCCAAACCGGCT }\end{array}$ & 644 \\
\hline Hypothetical protein FLJ20360 & $\begin{array}{l}\text { FLJ-1604F: } \quad \text { CACAGCCCAGGCTGTTCT } \\
\text { FLJ-2000R: CCCCACAGGCATACCAAC }\end{array}$ & 397 \\
\hline Stanniocalcin 2 (STC2) & $\begin{array}{l}\text { STC2-1707F: AAGGGAGTGGCCCCTATG } \\
\text { STC2-2105R: GCCAGGACGCAGCTTTAC } \\
\text { STC2-128F: AAGAACCATGTGTGCCGAG } \\
\text { STC2-1072R: GGAAAGATTTCGTGGCCA }\end{array}$ & $\begin{array}{l}399 \\
945\end{array}$ \\
\hline Hypothetical protein MGC4504 & $\begin{array}{l}\text { MGC-645F: TGGCAGACTTCATGCAGC } \\
\text { MGC-1175R: TTCCCAGGGCTATGGATG }\end{array}$ & 531 \\
\hline Zinc finger protein $36, \mathrm{C} 3 \mathrm{H}$ type-like 2 (ZFP36L2) & $\begin{array}{l}\text { ZFP36-1922F: ACTCGAACTCTGTGCCGG } \\
\text { ZFP36-2367R: ACCTATGGGCTGAGGGCT }\end{array}$ & 446 \\
\hline Vaccinia related kinase 1 (VRK1) & $\begin{array}{l}\text { VRK1-830F: TCCAATGGCTTACTGGCC } \\
\text { VRK-1246R: TGGTTCTTGAACGGGTCTG }\end{array}$ & 417 \\
\hline Neuronal PAS domain protein 2 (NPAS2) & $\begin{array}{l}\text { NPAS2-2280F: ACTTCAGCCATGATCGGC } \\
\text { NPAS2-2746R: CTGGAGGCCTGACGACTC }\end{array}$ & 467 \\
\hline Myeloid cell differentiation protein (MCL1) & $\begin{array}{l}\text { MCL1-1109F: ATATTTTGGGCTTGGGGC } \\
\text { MCL1-1433R: CCCTTCCTGGCACAGCTA }\end{array}$ & 325 \\
\hline Coatomer protein complex, epsilon (COPE) & $\begin{array}{l}\text { COPE-308F: ACTACCTCGCCCACGAGA } \\
\text { COPE-828R: GTGCTGGGACAGGACGAT }\end{array}$ & 520 \\
\hline Nucleotide binding protein (MinD homolog) & $\begin{array}{l}\text { NUBP1-643F: CAACTTCTGCCGCAAGGT } \\
\text { NUPB1-1106R: GAAAGTGGCTTCGGACCA }\end{array}$ & 464 \\
\hline Ornithine decarboxylase antizyme 2 (OAZ2) & $\begin{array}{l}\text { OAZ2-1304F: GTGTGCATTTGCGTCTGG } \\
\text { OAZ2-1775R: GGGCAGGCCACTTCTACA }\end{array}$ & 472 \\
\hline
\end{tabular}

ed by DNA chip analysis, RT-PCR was performed (Noh et al., 2001). To synthesize first strand cDNA, one microgram of RNA and $1 \mu$ of $10 \mu \mathrm{M}$ oligodT (T25NN) were mixed to a final reaction volume of 5 $\mu \mathrm{l}$ and heated for $2 \mathrm{~min}$ at $72^{\circ} \mathrm{C}$. After cooling on ice for $2 \mathrm{~min}, \mathrm{RT}$ was performed for $2 \mathrm{~h}$ at $42^{\circ} \mathrm{C}$ in a $10 \mu$ reaction mixture containing $50 \mathrm{mM}$ Tris- $\mathrm{HCl}, \mathrm{pH}$ 8.3, $75 \mathrm{mM} \mathrm{KCl}, 6 \mathrm{mM} \mathrm{MgCl}$, $2 \mathrm{mM}$ DTT, $1 \mathrm{mM}$ dNTP mix and 200 units $M M L V$ reverse transcriptase. Following incubation for $10 \mathrm{~min}$ at $72^{\circ} \mathrm{C}$, the reaction mixture was stored at $-70^{\circ} \mathrm{C}$. Genes showing differential expression after $A \beta$ treatment were amplified by PCR from the first strand CDNA. All primers used are summarized in Table 1. PCR was performed in a 20 $\mu \mathrm{l}$ reaction volume containing $10 \mathrm{mM}$ Tris- $\mathrm{HCl}, \mathrm{pH}$ $8.5,50 \mathrm{mM} \mathrm{KCl}, 1.5 \mathrm{mM} \mathrm{MgCl} 2,200 \mu \mathrm{M}$ dNTPs, 1 $\mathrm{U}$ Taq polymerase, $1 \mu \mathrm{l}$ first-strand CDNA, and 200 $\mathrm{nM}$ primers. The reactions were initial denaturation for $4 \mathrm{~min}$ at $95^{\circ} \mathrm{C}$, then 30 cycles of; $94^{\circ} \mathrm{C} 15 \mathrm{~s}, 60^{\circ} \mathrm{C}$ $15 \mathrm{~s}, 72^{\circ} \mathrm{C} 1 \mathrm{~min}$; and final extension at $72^{\circ} \mathrm{C}$ for 10 min. The amplified PCR products were separated in a $1.5 \%$ agarose gel containing ethidium bromide and visualized on a UV transilluminator. The levels of amplified DNAs by RT-PCR were quantified using the UTHSCSA ImageTool program (developed at the University of Texas Health Science Center at San Antonio, Texas and available from http://ddsdx.uthscsa.edu/dig/itdesc.html) by averaging three separate 
measurements of each band as well as control.

\section{Cloning of human RTP801 and STC2}

Human RTP801 and STC2 cDNAs were amplified from total RNAs extracted from CHP134 cells by RT-PCR. The amplified DNA was eluted from the gel using a Qiagen gel extraction kit. The eluted RTP801 and STC2 DNAs were then ligated into PCR3.1 vectors using a pCR3.1 TA cloning kit and a Ready-to-go T4 DNA ligase mix. The resulting construct was verified by dideoxy sequencing.

\section{Transient expression of RTP801 and STC2}

pCR3.1/RTP801 and pCR3.1/STC2 plasmids were transfected into CHP134 cells using the jetPEI transfection reagent (Qbiogene, Carlsbad, CA) according to the manufacturer's protocols. The transient expressions of RTP801 and STC2 were confirmed by semiquantitative RT-PCR.

\section{Statistical analysis}

Values are expressed as means $\pm S D$. The Student's $t$-test was employed for the analyses. A $P$-value of less than 0.05 was considered statistically significant.

\section{Results}

\section{A $\beta$ cytotoxicity in CHP134 cells}

Cells were treated with 1,3 and $10 \mu \mathrm{M} \mathrm{A} \beta$ in media containing $2 \%$ FBS for 4 days and cell survival was determined by MTT assay. Cell survival decreased in a dose dependent manner and treatment with $10 \mu \mathrm{M}$ A $\beta$ resulted in significant cell death $(P<0.05)$ compared to the untreated cells (Figure 1).

\section{CDNA chip analysis}

To identify differentially expressed genes in A $\beta$-treated cells, we used cDNA chips spotted 3,100 human cDNAs derived from the papilla cells of hair follicles. RNA was prepared from CHP134 cells treated with or without $10 \mu \mathrm{M} \mathrm{A} \beta$ for 1 and for $6 \mathrm{~h}$. The initial analysis of the expression data from the cDNA microarrays indicated that the abundance of 13 genes changed 1.5-fold or more during the course of $A \beta$ treatment (Table 2). In order to confirm the induction or repression of the 13 genes, semiquantitative RTPCR was performed using cDNAs prepared from the RNAs of A $\beta$-treated or -untreated cells. Six of 13 genes, RTP801, stanniocalcin 2 (STC2), hypothetical protein MGC4504, Hi95/sestrin 2 (SEST2), hypothetical protein FLJ20360, and zinc finger protein 36 (ZFP36L2) were confirmed to be $A \beta$-responsive (Figure 2).

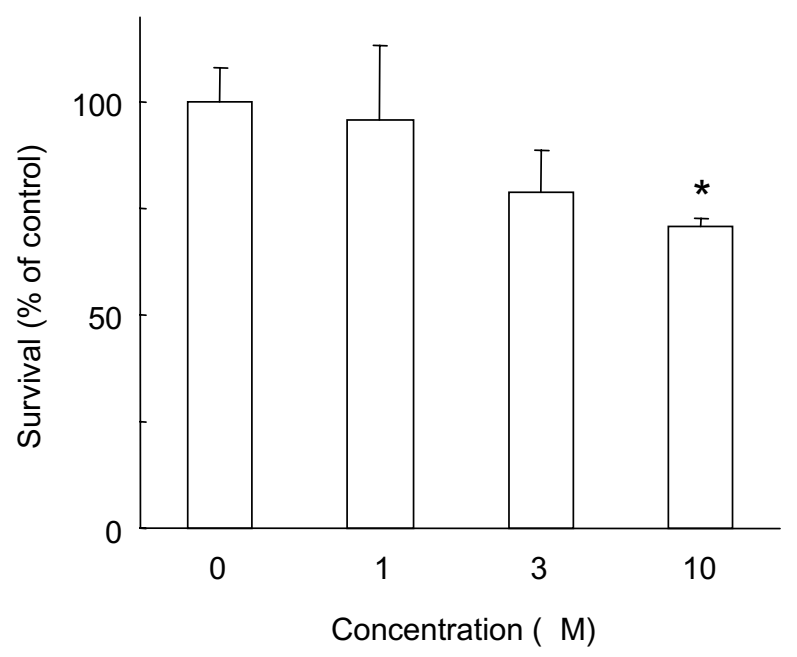

Figure 1. A $\beta$-induced cell death in CHP134 cells. Cells were treated with the indicated concentrations of $A \beta$ (1-42) and then incubated for 4 days. Cell survival was measured by MTT assay. Values are means $\pm S D$ of triplicates of 3 independent experiments. ${ }^{*}, P<0.05$ (Student's $t$-test).

\section{Induction of RTP801, STC2 and Hi95/SEST2 during $A \beta$ treatment}

We further analyzed the expressions of 3 genes, RTP801, Hi95/SEST2, and STC2, with functions known to be associated with the oxidative stress induced by hypoxia (Budanov et al., 2002; Shoshani et al., 2002), and calcium and phosphate homeostasis (Ishibashi et al., 1998), respectively. The levels of these genes were also found to be increased in dose- and timedependent manners in A $\beta$-treated cells by RT-PCR (Figure 3).

\section{Effects of RTP801 and STC2 on A $\beta$-mediated cytotoxicity}

In an attempt to investigate the effects of RTP801 and STC2 on $A \beta$ toxicity, the protein encoding regions of RTP801 and STC2 were amplified by RT-PCR and subcloned into a PCR3.1 vector under the control of a cytomegalovirus promoter. The expressions of RTP801 and STC2 were increased in the RTP801- or STC2transfected cells compared to the vector transfected cells (Figure 4). Transient expression of the sense RTP801 gene in the cells showed an increase in the A $\beta$ cytotoxicity $(P<0.01)$, and the expression of the antisense RTP801 gene had a protective effect against $A \beta$ toxicity $(P<0.05)$ compared to the vectortransfected cells (Figure 5). Transient expression of the sense or the antisense STC2 gene had little effects on $A \beta$ cytotoxicity (Figure 5 ). These results suggest that RTP801 might be involved in $A \beta$ cytotoxicity 
Table 2. AB-induced or repressed genes in CHP134 cells.

\begin{tabular}{|c|c|c|c|c|c|}
\hline \multirow{2}{*}{ Gene name } & \multicolumn{2}{|c|}{ Folds } & \multirow{2}{*}{$\begin{array}{l}\text { Genbank } \\
\text { Acc. No. }\end{array}$} & \multirow{2}{*}{ Function } & \multirow{2}{*}{ RT-PCR* } \\
\hline & $1 \mathrm{~h}$ & $6 \mathrm{~h}$ & & & \\
\hline Stanniocalcin 2 (STC2) & 0.77 & 1.85 & M_003714 & $\begin{array}{l}\text { Calcium and phosphate } \\
\text { homeostasis }\end{array}$ & 1.41 \\
\hline ypothetical protein MGC4504 & 0.88 & 1.79 & NM_024111 & Unknown & 1.36 \\
\hline TP801 & 0.92 & 1.71 & NM_019058 & Cell viability & 1.53 \\
\hline Hi95/Sestrin 2 (SEST2) & 0.79 & 1.63 & NM_031459 & Cell viability & 1.45 \\
\hline $\begin{array}{l}\text { Myeloid cell differentiation } \\
\text { protein }(M C L 1)\end{array}$ & 0.95 & 0.60 & L08246 & Apoptosis & 1.08 \\
\hline Down syndrome candidate & 0.83 & 0.62 & NM_004414 & $\begin{array}{l}\text { CNS development \& } \\
\text { transcriptional function }\end{array}$ & 0.90 \\
\hline $\begin{array}{l}\text { Ornithine decarboxylase } \\
\text { antizyme } 2 \text { (OAZ2) }\end{array}$ & 0.91 & 0.66 & NM_002537 & $\begin{array}{l}\text { Regulation of polyamine } \\
\text { synthesis }\end{array}$ & 1.07 \\
\hline $\begin{array}{l}\text { Coatomer protein complex, } \\
\text { epsilon }(C O P E)\end{array}$ & 1.06 & 0.60 & NM_007263 & Vesicle trafficking & 0.90 \\
\hline Hypothetical protein FLJ20360 & 0.72 & 0.65 & NM_017782 & Unknown & 0.77 \\
\hline $\begin{array}{l}\text { Nucleotide binding protein } \\
\quad(\text { MinD homolog) }\end{array}$ & 0.82 & 0.61 & NM_002484 & Nucleotide binding & 0.96 \\
\hline $\begin{array}{l}\text { Zinc finger protein } 36, \\
\text { C3H type-like } 2 \text { (ZFP36L2) }\end{array}$ & 0.92 & 0.65 & NM_006887 & Transcription factor & 0.47 \\
\hline $\begin{array}{l}\text { Vaccinia related kinase } 1 \\
\quad(\text { VRK1) }\end{array}$ & 0.95 & 0.64 & NM_003384 & Circardian rhythms & 0.90 \\
\hline $\begin{array}{l}\text { Neuronal PAS domain } \\
\text { protein } 2 \text { (NPAS2) }\end{array}$ & 0.87 & 0.59 & NM_002518 & DNA binding & No band \\
\hline
\end{tabular}

*Values are mean ratios of DNA levels amplified from $A \beta$ (1-42)-treated cells to those from the untreated control.

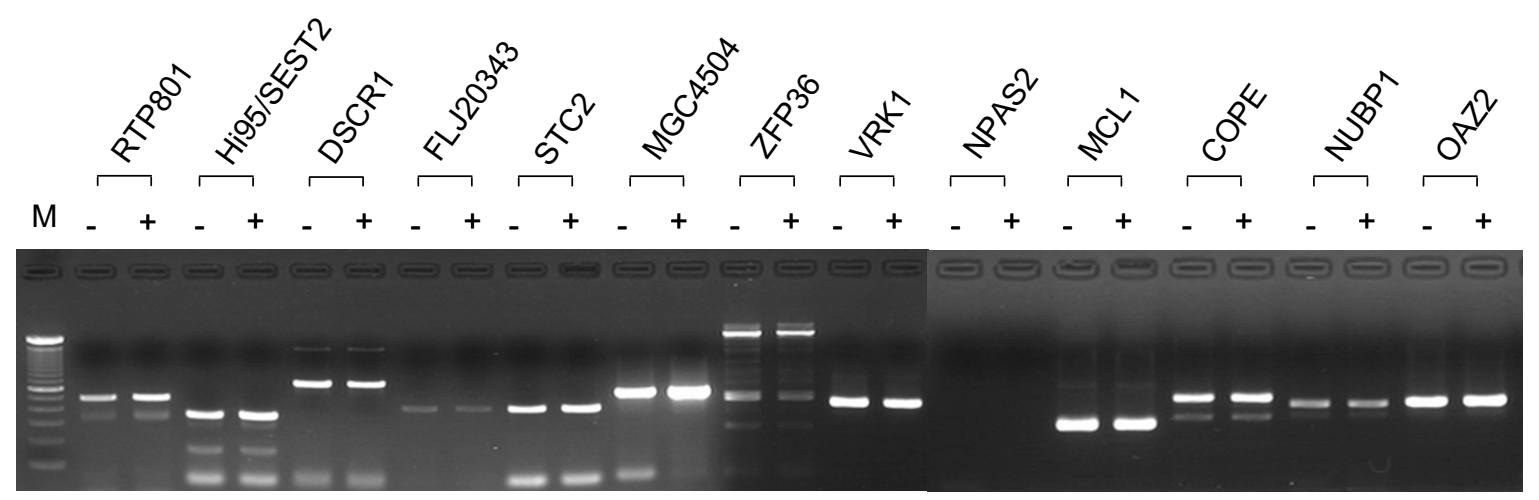

Figure 2. RT-PCR analysis of A $\beta$-responsive genes. Cells were incubated in the absence $(-)$ or in the presence $(+)$ of $10 \mu \mathrm{M}$ of $A \beta(1-42)$ for $6 \mathrm{~h}$ and harvested. RNAs were purified from the cells and the 1st-strand cDNAs were synthesized with reverse transcriptase. Target sequences for the specific genes were amplified by PCR and the amplified DNAs were analyzed by agarose gel electrophoresis. M, 100 bp ladder. The figure shows representative data from 3 independent experiments. 
A

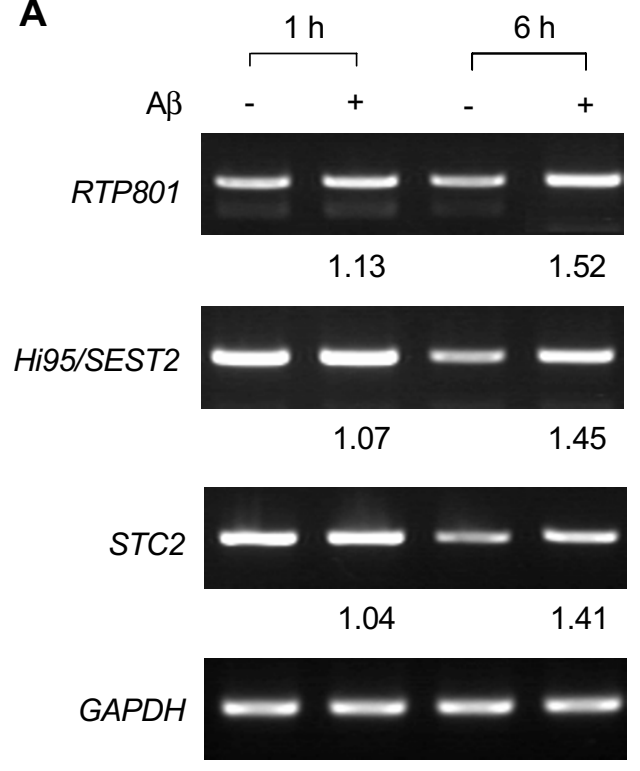

B

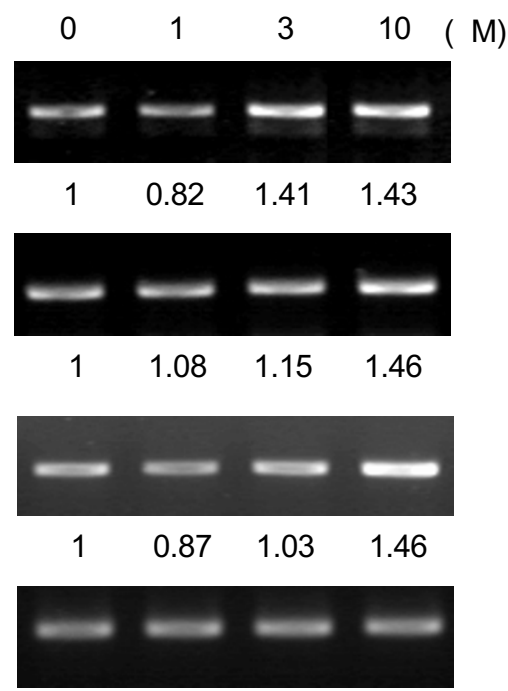

Figure 3. Expressions of RTP801, STC2, and Hi95/SEST2 in CHP134 cells treated with A 3 . A. Cells were incubated in the absence (-) or in the presence $(+)$ of $10 \mu \mathrm{M}$ of $A \beta$ (1-42) for 1 and for $6 \mathrm{~h}$, and harvested. RTP801 and STC2 were amplified by RT-PCR. B. Cells were treated with the indicating concentrations of $A \beta(1-42)$ for $6 \mathrm{~h}$ and harvested. RTP801 and STC2 were amplified by RT-PCR. The amplified DNAs were analyzed by agarose gel electrophoresis and their levels were quantified using a UTHSCSA ImageTool program by averaging three separate measurements of each band as well as control. This shows representative data from 3 independent experiments.

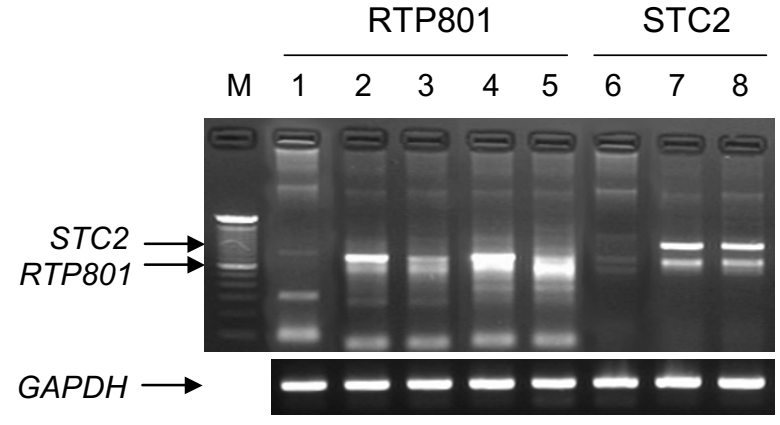

Figure 4. semiquantitative RT-PCR of RTP801 and STC2 in CHP134 cells transfected with PCR3.1/RTP801 or PCR3.1/STC2 vectors. CHP134 cells were transfected with pCR3.1/RTP801 or pCR3.1/STC2 using a jetPEI transfection reagent. After 3 days, cells were harvested and RNAs were extracted. Transient expression of RTP801 and STC2 were confirmed by RT-PCR. RTP-183F and RTP-913R were used in Lane 1 to 5 and STC2-128F and STC2-1072R in Lane 6 to 8. Lanes 1 and 6, vector-transfected cells; Lanes 2 and 3, sense RTP801; Lanes 4 and 5, antisense RTP801; Lanes 7, sense STC2; Lane 8, antisense STC2. M, 100 bp ladder.

and in the pathogenesis of Alzheimer's disease.

\section{Discussion}

In the present study we identified six genes as being
A $\beta$-responsive in CHP134 cells by cDNA chip analysis and RT-PCR. RTP801, Hi95/SEST2 and STC2 were overexpressed in CHP134 cells treated with $A \beta$ and the transient expression of RTP801 increased their sensitivity to $A \beta$ cytotoxicity. RTP 801 was induced by hypoxia in rat $\mathrm{C} 6$ glioma cells regulated by hypoxiainducible factor-1 (HIF-1) and identified to be involved in apoptosis (Shoshani et al., 2002). Although expression of the RTP801 gene in MCF7 and PC12 cells inhibited hypoxia- and $\mathrm{H}_{2} \mathrm{O}_{2}$-mediated apoptosis, its function in cells is not fully understood. RTP801 is ubiquitously expressed in multiple human tissues at low levels. However, in response to hypoxia its transcription increases rapidly and sharply. The inducible expression of RTP801 in cells has different biological effects depending on the cell context. Shoshani et al. (2002) showed that expression of RTP801 has protected MCF7 and PC12 cells from hypoxia and from $\mathrm{H}_{2} \mathrm{O}_{2}$-triggered apoptosis, but detrimentally affected nondividing neuron-like PC12 cells under hypoxia and oxidative stress.

We identified that Hi95/SEST2 expression was also increased in A $\beta$-treated CHP134 cells. Hi95/SEST2 has been recently identified as a novel stress-responsive gene involved in the regulation of cell viability (Budanov et al., 2002). Hi95/SEST2 shares significant homology with a p53-regulated GADD family member PA26 (Peeters et al., 2003). Increased expression of Hi95/SEST2 was induced by various cellular stresses 


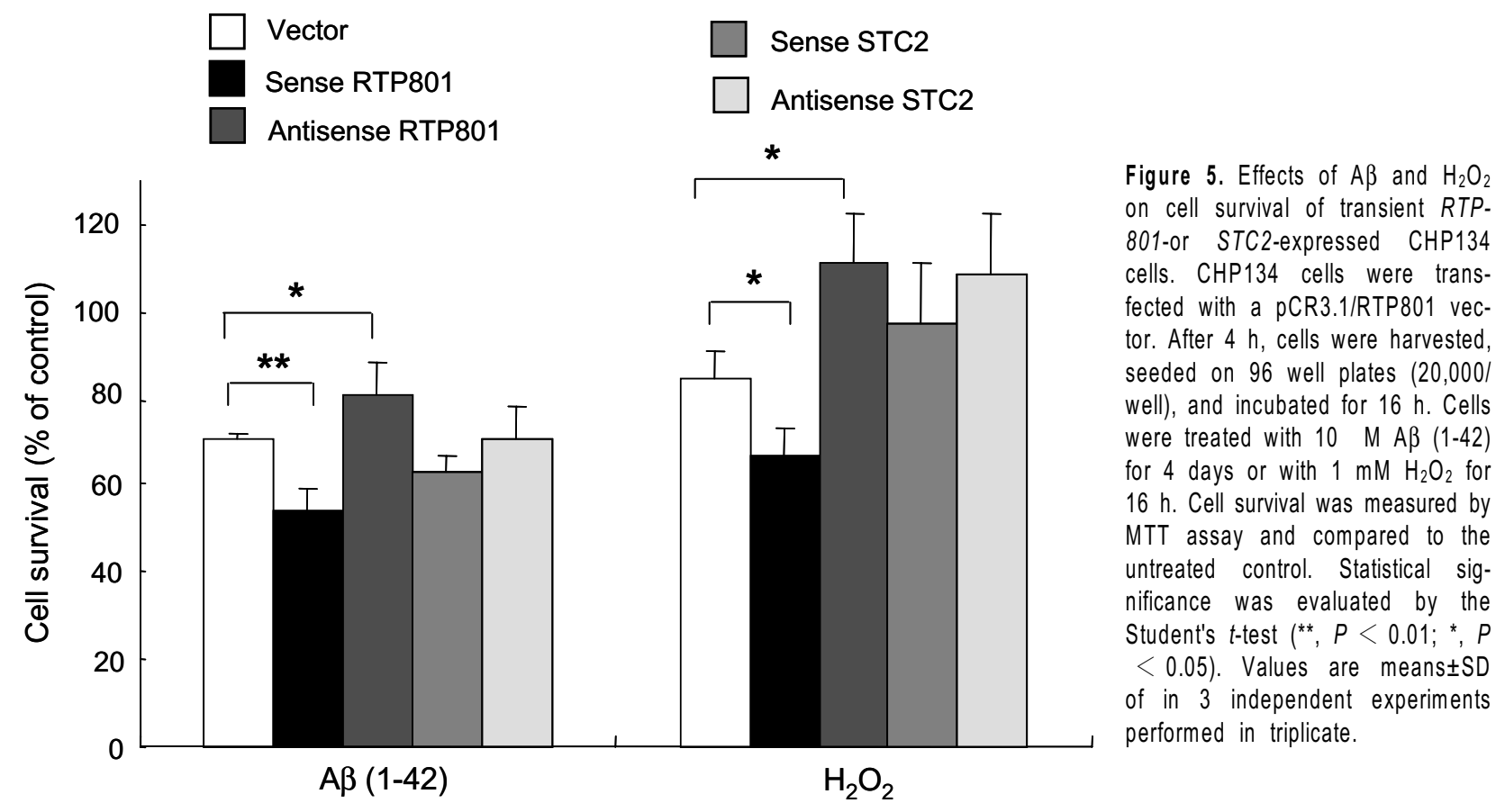

including prolonged hypoxia, oxidative stress, UV-or $\gamma$-irradiation, and doxorubicin, and the overexpression of Hi95/SEST2 full-length CDNA was found to be toxic in many types of cultured cells (Budanov et al., 2002).

Hypoxia is known to induce oxidative stress in PC12 cells via $A \beta$ and reactive oxygen species formation (Green et al., 2002). A $\beta$ also induces oxidative stress itself by producing $\mathrm{H}_{2} \mathrm{O}_{2}$ (Behl et al., 1994; Huang et al., 1999). Therefore, the A $\beta$-mediated overexpressions of RTP801 and Hi95/SEST2 genes in CHP134 cells might be associated with cellular oxidative stress. Our finding that the transient expression of the sense RTP801 gene, not the antisense RTP801 gene, exacerbates $\mathrm{A} \beta$-or $\mathrm{H}_{2} \mathrm{O}_{2}$-mediated cytotoxicity in CHP134 cells suggests that the overexpression of RTP801 in A $\beta$-treated CHP134 cells might play an important role in cell death during $A \beta$-mediated oxidative stress.

Stanniocalcin (STC) is a hormone that was initially identified in fish, which inhibits calcium absorption in the gills and intestines and stimulates the absorption of phosphates (Sundell et al., 1992). Mammalians have two types of STC; STC1 and STC2. STC1 has a $61 \%$ homology with fish STC and presents in kidney, thyroid glands, ovary, and prostates. STC2 has a $38 \%$ homology with fish STC2 and presents mainly in the pancreas (Ishibashi et al., 1998). Mammalian STC1 was suggested to play an important role in calcium homeostasis, including the absorption and secretion of calcium and phosphates. However, the function of STC2 is unknown (Jellinek et al., 2000). STC2 might also play an important role in glucose homeostasis (Moore et al., 1999), and was identified as an estrogen-responsive gene, which was induced with estrogen receptor in human breast cancers (Bouras et al., 2002). Our data shows that STC2 is up-regulated by $A \beta$ treatment. However, the transient expression of sense or antisense STC2 genes was found to have little effects on $A \beta$ cytotoxicity, suggesting that the $A \beta$-mediated overexpression of STC2 may not be directly associated with $A \beta$ toxicity.

In conclusion, our results suggest that some of the novel $A \beta$-responsive genes play key roles in the response of neuronal cells to $A \beta$ exposure. Further functional analysis of the novel $A \beta$-responsive genes is required to open up new research routes of enquiry into the pathogenesis of $A D$.

\section{Acknowledgement}

This work was supported by grant No. R01-1999-00000087 from the Korea Science \& Engineering Foundation.

\section{References}

Aksenov MY, Aksenova MV, Carney JM, Butterfield DA. Oxidative modification of glutamine synthetase by amyloid $\beta$ peptide. Free Radic Res 1997;27:267-81

Aksenov MY, Aksenova MV, Markesbery WR, Butterfield DA. Amyloid $\beta$-peptide (1-40)-mediated oxidative stress in cultured hippocampal neurons. Protein carbonyl formation, CK BB expression, and the level of $\mathrm{Cu}, \mathrm{Zn}$, and Mn SOD mRNA. J 
Mol Neurosci 1998;10:181-92

Behl C, Davis JB, Lesley R, Schubert D. Hydrogen peroxide mediates amyloid $\beta$ protein toxicity. Cell 1994;77:817-27

Bouras T, Southey MC, Chang AC, Reddel RR, Willhite D, Glynne R, Henderson MA, Armes JE, Venter DJ. Stanniocalcin 2 is an estrogen-responsive gene coexpressed with the estrogen receptor in human breast cancer. Cancer Res 2002;62:1289-95

Budanov AV, Shoshani T, Faerman A, Zelin E, Kamer I, Kalinski H, Gorodin S, Fishman A, Chajut A, Einat P, Skaliter R, Gudkov AV, Chumakov PM, Feinstein E. Identification of a novel stress-responsive gene Hi95 involved in regulation of cell viability. Oncogene 2002;21:6017-31

Butterfield DA, Hensley K, Harris M, Mattson M, Carney J. $\beta$-Amyloid peptide free radical fragments initiate synaptosomal lipoperoxidation in a sequence-specific fashion: implications to Alzheimer's disease. Biochem Biophys Res Commun 1994;200:710-5

Chomczynski $P$, Sacchi N. Single-step method of RNA isolation by acid guanidinium thiocyanate-phenol-chloroform extraction. Anal Biochem 1987;162:156-9

Green KN, Boyle JP, Peers C. Hypoxia potentiates exocytosis and $\mathrm{Ca}^{2+}$ channels in PC12 cells via increased amyloid $\beta$ peptide formation and reactive oxygen species generation. J Physiol 2002;541:1013-23

Greeve I, Hermans-Borgmeyer I, Brellinger C, Kasper D, Gomez-Isla T, Behl C, Levkau B, Nitsch RM. The human DIMINUTO/DWARF1 homolog seladin-1 confers resistance to Alzheimer's disease-associated neurodegeneration and oxidative stress. J Neurosci 2000;20:7345-52

Hata R, Masumura M, Akatsu H, Li F, Fujita H, Nagai $Y$, Yamamoto T, Okada H, Kosaka K, Sakanaka M, Sawada $T$. Up-regulation of calcineurin $A \beta$ mRNA in the Alzheimer's disease brain: assessment by CDNA microarray. Biochem Biophys Res Commun 2001;284:310-6

Huang X, Cuajungco MP, Atwood CS, Hartshorn MA, Tyndall JD, Hanson GR, Stokes KC, Leopold M, Multhaup G, Goldstein LE, Scarpa RC, Saunders AJ, Lim J, Moir RD, Glabe C, Bowden EF, Masters CL, Fairlie DP, Tanzi RE, Bush Al. $\mathrm{Cu}$ (II) potentiation of Alzheimer $A \beta$ neurotoxicity: Correlation with cell-free hydrogen peroxide production and metal reduction. J Biol Chem 1999;74:37111-6

Ishibashi K, Miyamoto K, Taketani Y, Morita K, Takeda E, Sasaki S, Imai M. Molecular cloning of a second human stanniocalcin homologue (STC2). Biochem Biophys Res Commun 1998;250:252-8

Jang $\mathrm{JH}$, Surh YJ. $\beta$-Amyloid induces oxidative DNA damage and cell death through activation of c-Jun $\mathrm{N}$ terminal kinase. Ann N Y Acad Sci 2002;973:228-36

Jellinek DA, Chang AC, Larsen MR, Wang X, Robinson PJ, Reddel RR. Stanniocalcin 1 and 2 are secreted as phosphoproteins from human fibrosarcoma cells. Biochem J 2000; 350:2453-61

Kaltschmidt B, Uherek M, Wellmann H, Volk B, Kaltschmidt C. Inhibition of NF- $\mathrm{KB}$ potentiates amyloid $\beta$-mediated neuronal apoptosis. Proc Natl Acad Sci USA 1999;96:9409-14

Lovell MA, Gabbita SP, Markesbery WR. Increased DNA oxidation and decreased levels of repair products in Alzheimer's disease ventricular CSF. J Neurochem 1999;72: $771-6$

Maccioni RB, Otth C, Concha II, Munoz JP. The protein kinase Cdk5. Structural aspects, roles in neurogenesis and involvement in Alzheimer's pathology. Eur J Biochem 2001; 268:1518-27

Marcus DL, Strafaci JA, Miller DC, Masia S, Thomas CG, Rosman J, Hussain S, Freedman ML. Quantitative neuronal $\mathrm{c}$-fos and c-jun expression in Alzheimer's disease. Neurobiol Aging 1998;19:393-400

Mark RJ, Blanc EM, Mattson MP. Amyloid $\beta$-peptide and oxidative cellular injury in Alzheimer's disease. Mol Neurobiol 1996;12:211-24

Markesbery WR. Oxidative stress hypothesis in Alzheimer's disease. Free Radic Biol Med 1997;23:134-47

Mattson MP, Guo Q, Furukawa K, Pedersen WA. Presenilins, the endoplasmic reticulum, and neuronal apoptosis in Alzheimer's disease. J Neurochem 1998;70:1-14

Miranda S, Opazo C, Larrondo LF, Munoz FJ, Ruiz F, Leighton $F$, Inestrosa NC. The role of oxidative stress in the toxicity induced by amyloid $\beta$-peptide in Alzheimer's disease. Prog Neurobiol 2000;62:633-48

Moore EE, Kuestner RE, Conklin DC, Whitmore TE, Downey W, Buddle MM, Adams RL, Bell LA, Thompson DL, Wolf A, Chen L, Stamm MR, Grant FJ, Lok S, Ren H, De Jongh KS. Stanniocalcin 2: characterization of the protein and its localization to human pancreatic cells. Horm Metab Res 1999;31:406-14

Noh YH, Kim JA, Lim GR, Ro YT, Koo JH, Lee YS, Han DS, Park HK, Ahn MJ. Detection of circulating tumor cells in patients with gastrointestinal tract cancer using RT-PCR and its clinical implications. Exp Mol Med 2001;33:8-14

Pappolla MA, Omar RA, Kim KS, Robakis NK. Immunohistochemical evidence of oxidative stress in Alzheimer's disease. Am J Pathol 1992;140:621-8

Paradis E, Douillard H, Koutroumanis M, Goodyer C, LeBlanc A. Amyloid $\beta$ peptide of Alzheimer's disease downregulates $\mathrm{Bcl}-2$ and upregulates bax expression in human neurons. J Neurosci 1996;16:7533-9

Park GH, Choe J, Choo HJ, Park YG, Sohn J, Kim MK. Genome-wide expression profiling of 8-chloroadenosine- and 8-chloro-cAMP-treated human neuroblastoma cells using radioactive human cDNA microarray. Exp Mol Med 2002;34: 184-93

Peeters $H$, Debeer $P$, Bairoch A, Wilquet $V$, Huysmans C, Parthoens E, Fryns JP, Gewillig M, Nakamura Y, Niikawa N, Van De Ven W, Devriendt K. PA26 is a candidate gene for heterotaxia in humans: identification of a novel PA26related gene family in human and mouse. Hum Genet 2003; 112:573-80.

Santiard-Baron D, Gosset $P$, Nicole A, Sinet PM, Christen $Y$, Ceballos-Picot I. Identification of $\beta$-amyloid-responsive genes by RNA differential display: early induction of a DNA damage-inducible gene, gadd45. Exp Neurol 1999;158:20613

Schippling S, Kontush A, Arlt S, Buhmann C, Sturenburg HJ, 
Mann U, Muller-Thomsen T, Beisiegel U. Increased lipoprotein oxidation in Alzheimer's disease. Free Radic Biol Med 2000;28:351-60

Shoshani T, Faerman A, Mett I, Zelin E, Tenne T, Gorodin S, Moshel Y, Elbaz S, Budanov A, Chajut A, Kalinski $H$, Kamer I, Rozen A, Mor O, Keshet E, Leshkowitz D, Einat $P$, Skaliter R, Feinstein E. Identification of a novel hypoxiainducible factor 1-responsive gene, RTP801, involved in apoptosis. Mol Cell Biol 2002;22:2283-93

Smith CD, Carney JM, Starke-Reed PE, Oliver CN, Stadtman ER, Floyd RA, Markesbery WR. Excess brain protein oxidation and enzyme dysfunction in normal aging and in Alzheimer disease. Proc Natl Acad Sci USA 1991;88:10540-3

Smith MA, Rottkamp CA, Nunomura A, Raina AK, Perry G. Oxidative stress in Alzheimer's disease. Biochim Biophys Acta 2000;1502:139-44

Suh SW, Jensen KB, Jensen MS, Silva DS, Kesslak PJ, Danscher G, Frederickson CJ. Histochemically-reactive zinc in amyloid plaques, angiopathy, and degenerating neurons of Alzheimer's diseased brains. Brain Res 2000;852:274-8
Sundell K, Bjornsson BT, Itoh H, Kawauchi H. Chum salmon (Oncorhynchus keta) stanniocalcin inhibits in vitro intestinal calcium uptake in Atlantic cod (Gadus morhua). J Comp Physiol [B] 1992;162:489-95

Thompson CM, Markesbery WR, Ehmann WD, Mao YX, Vance DE. Regional brain trace-element studies in Alzheimer's disease. Neurotoxicology 1988;9:1-7

Vitek MP, Bhattacharya K, Glendening JM, Stopa E, Vlassara $H$, Bucala R, Manogue K, Cerami A. Advanced glycation end products contribute to amyloidosis in Alzheimer disease. Proc Natl Acad Sci USA 1994;91:4766-70

Walker DG, Lue LF, Beach TG. Gene expression profiling of amyloid $\beta$ peptide-stimulated human post-mortem brain microglia. Neurobiol Aging 2001;22:957-66 